\title{
Basidiomycetes at the timberline in Lapland 1. Introduction
}

\author{
PERTTI RENVALL, TARJA RENVALL and TUOMO NIEMELÄ
}

\begin{abstract}
RENVALL, P., RENVALL, T. \& NIEMELÄ, T. 1991: Basidiomycetes at the timberline in Lapland 1. Introduction. - Karstenia 31:1-12.

Basidiomycetes, especially the wood-inhabiting fungi, were studied in the Värrio Strict Nature Reserve, the Urho Kekkonen National Park and adjacent areas in Finnish East Lapland, which contain some of the last remnants or primeval, Northern Boreal forest at and near the alpine and polar timberline. The qualitative and quantitative composition of the fungi, as indicated by their fruit body production, was studied in naturally regenerating virgin forests and the area of a fairly recent forest fire, special attention being paid both to species recognized as threatened in Finland and to potentially threatened fungi. The area is also affected by long-distance air pollution from the mining and metal industry in the western Murmansk Region, Russia. The main woody plants decayed by basidiomycetes in the region are Pinus sylvestris L., Picea abies (L.) Karsten subsp. obovata (Ledeb.) Domin and Betula pubescens Ehrh. subsp. czerepanovii (Orlova) Hämet-Ahti. A general biogeographical and ecological outline of the study area is presented.
\end{abstract}

Key words: Basidiomycetes, environmental change, Finland, Lapland, Northern Boreal, primeval forest, threatened fungi, timberline

Pertii Renvall, Tarja Renvall \& Tuomo Niemelä, Botanical Museum, University of Helsinki, Unioninkatu 44, SF-00170 Helsinki, Finland

\section{Foreword}

The best-preserved areas of virgin or almost virgin forests in Europe are found in the extreme north. The northern timberline regions of Finland, northern parts of Norway and Sweden, and adjacent parts of the Soviet Union - much of which is often called Lapland - have long escaped intensive forestry and land use, because of the slow growth of tree and the sparse human population. Even now those hinterlands offer extensive patches of true wilderness with virgin forests and no permanent settlements. Corresponding areas can be found in the Northern Boreal zone of the Soviet Union, Alaska and Canada.

Such ecosystems are especially vulnerable. In the Nordic countries there are large national parks in the north, where the old forests are fairly well preserved, but other forest areas are becoming fragmented with new roads, recreational constructions and other human activities. Intensive modern forestry practices, including clear-cutting, often followed by ploughing of the forest soil and artificial regeneration of tree species, are now realities in Finland. The presence of valuable ore and mineral deposits has led to largescale mining, especially in the Murmansk Region, which is spreading air pollution to a catastrophic degree. Artificial water reservoirs constructed to serve hydroelectric power plants have destroyed wide areas of rich valley vegetation. For many reasons, it will soon be too late to study the original mycoflora of the old forests in northernmost Europe.

Due to the natural regeneration of the old forests, the mycoflora of Lapland is of special interest. We can expect to find that the delicate balance of fungal co-occurrence is still undisturbed in many old biotopes of the North. Only recently have mycologists come to realize the dangers that environmental changes and the degradation of nature may represent for the fungi. In Finland, the first Red List (Rassi et al. 1986, Rassi \& Väisänen 1987) reported that 267 
species of fungi (including microfungi and lichens) are threatened in the country. It soon became evident that far more species should be included, and a proposal for an expanded list of threatened fungi has already been made, including about 250 additional species. Even that estimate is too optimistic, because very many species, though still fairly common, are diminishing in abundance.

The present paper is an introduction to a series of studies devoted to the forest basidiomycetes of Lapland, particularly northeastern Finland. Since the area is almost unexplored as regards the mycoflora, several aspects of the basidiomycetes, especially the wood-inhabiting fungi, call for our attention: the species composition, distribution, ecology, forest pathology and also some taxonomic problems. Special emphasis will be paid to threatened species.

This series will later include studies from other areas of Lapland, e.g., the western and northern parts. Those papers will contain introductions to the regions and surveys of special local problems.

\section{Material and methods}

Besides a check list of the polypores in northeastern Finland (Renvall et al. 1991), the ongoing series of papers is intended to include taxonomic revisions and some more extensive studies on the ecology, sociology and pathology, with special emphasis on the Lappish wood-rotting fungi. As the approaches will vary, details of the techniques employed in the studies will be given separately when needed.

The plan for these forthcoming publications is the result of a project supported by the Academy of Finland and to a lesser extent by other bodies. The Master's theses of the authors P. Renvall (1989) and T. Renvall (1989) have already been prepared from the material; see also Renvall and Niemelä (1990).

\section{Field work and documentation}

The field work was done by P. Renvall and T. Renvall in the biogeographic provinces of Koillismaa and Sompio Lapland in eastern Finnish Lapland. The study was initiated with a period of field work in August-September 1987. At that time, four weeks were spent in the Värriö Strict Nature Reserve (in the parishes of Salla and Savukoski), and one week in the Urho Kekkonen National Park (Sodankylä parish); 1259 records were made, mainly of wood-inhabiting basidiomycetes, and 427 specimens were collected. In 1988 the collecting and other field work was continued in July to September, with a six-week period in Värriö, one-week stay in the Urho Kekkonen National Park and shorter visits to an extensive forest-fire area in Tuntsa. Altogether, 2399 records of fungi were made and 551 specimens collected. After these main field work periods, the Värriö Strict Nature Reserve was revisited in August 1989 , in order to obtain information on the annual variation in the fruit body emergence and during this time 359 notes were made and 203 specimens collected.

The study areas were so selected that all the major forest site types were included and the profile of the forest communities was as complete as possible. The working routine was designed to provide maximal information on the forest fungal composition, as indicated by their production of fruit bodies, and the co-occurrence of different species, e.g., on the same trunks. When an observation concerned a wood-inhabiting species, each host tree was examined carefully to ascertain and record its size, general condition, state of decay, amount of epiphytes and other characters that could be considered to have some effect on the fungal mycelia growing inside. The general ecology of each study site, the local vegetation and the forest type were also recorded. All the basic data and, for instance, the way of rating the degree of decay will be presented in more detail in future papers.

The specimens collected are, or will be, preserved in the Botanical Museum of the University of Helsinki $(\mathrm{H})$, but a minor amount of reference specimens (mostly duplicates) will be kept in the personal collection of P. Renvall (abbreviated as P.R.) and in an educational collection of T. Niemelä (T.N.). The general planning of the whole project, and also its funding, were organised by T. Niemelä; details of the working routine were drawn up jointly. The field routine, data processing and discussions were the responsibility of P. Renvall and T. Renvall. They will also write the text for the forthcoming papers. This article was written mostly by P. Renvall while $T$. Niemelä assisted in preparing the final version of the paper. The previous literature was studied also by T. Renvall and the pictures in this paper were produced by P. Renvall. The sources of the illustrations will be indicated in the introductions of the future articles.

The forest type classification follows Kalela (1961), Kalliola (1973) and a mimeographed summary of Dr. Leena Hämet-Ahti (Helsinki), who has extensive experience of the vegetation of North Finland. Since this information is not readily available, a short description of the forest site types of the study area is included in this introduction. 


\section{Nomenclature}

The nomenclature of polypores is in a state of confusion. In the present series of studies we mostly follow Niemelä (1988), in an attempt to achieve an up-to-date species concept and generic division. The latest Code of Botanical Nomenclature (Greuter et al. 1988) caused some unwelcome name changes, and in some groups our generic division differs from that in recent manuals (e.g., Jülich 1984, Gilbertson \& Ryvarden 1986, 1987), which themselves disagree in some generic names and delimitations. The work of Eriksson et al. (1973 and later volumes) served as the basis for the identification of the corticiaceous fungi.

The names of the trees and shrubs are according to Hämet-Ahti et al. (1989) and the names of the other vascular plants according to Hämet-Ahti et al. (1986). The bryophyte nomenclature follows Koponen et al. (1977) and the lichen names were adopted from Ahti (1989). The authors of the scientific names can be found in the above papers, and are not repeated below.

\section{Previous studies}

The flora and vegetation of eastern Lapland have been studied fairly extensively (cf. Rintanen 1968, 1970a, b, Haapasaari 1988), but very few earlier mycological observations and collections are available from the area. P.A. Karsten made a long collecting journey to the Kola Peninsula of Russia in 1861, and published the bulk of his results (Karsten 1866). M. Laurila collected in Salla and Kuusamo on both sides of the present eastern border of Finland; extensive collections of this keen mycologist are now preserved in Helsinki $(\mathrm{H})$ and Turku (TUR). Laurila's early death in 1942 is the reason why only one paper (Laurila 1939) on his material was completed. Ulvinen et al. (1981) listed the fungi found in the Koillismaa biological province (Regio kuusamoënsis), which includes most of the Värriö Reserve in Salla. Most of that material, however, derives from Kuusamo parish, which lies about $150 \mathrm{~km}$ to the south of the present study area. While our research was done within a mosaic of Northern Boreal, orohemiarctic and oroarctic vegetation near the timberline, Kuusamo lies deep in the Northern Boreal zone and is covered by more closed, rich spruce forests, so that it does not fully correspond to our study area. Ulvinen (1963) and Kytövuori $(1989 a-c)$ have published some information on the fungi, especially agarics, in western parts of East Finnish Lapland.
Scattered data on basidiomycetes can be found in the study of Eriksson and Strid (1969) and some other papers listed below. Wood-rotting fungi in eastern Lapland outside the present study area have been collected extensively by Mr. Heikki Kotiranta and to a lesser extent by T. Niemelä. Most of the information on their collections is so far unpublished, but two reports (Kotiranta \& Larsson 1989, Kotiranta \& Saarenoksa 1990) on some noteworthy corticiaceous species have just been completed. The particular area of our study, the inner southeastern part of the Koilliskaira fjeld region is virtually undocumented, even with regards to its basic fungal flora.

More data on forest fungi are available from some other parts of northem Finland. Kallio and Kankainen $(1964,1966)$ reported on macrofungi in Inari and Utsjoki in northernmost Finland. Most collections reported by Eriksson and Strid (1969) derive from the Pisavaara Strict Nature Reserve and the Pallas-Ounastunturi National Park; a great deal of their material was collected jointly with Prof. Viljo Kujala. Norokorpi (1979) studied decay-causing fungi of Norway Spruce (Picea abies) in northern Finland, using cultural isolations in addition to fruit bodies. For the polypore survey of Finland (cf. Niemelä 1982), H. Kotiranta and T. Niemelä have repeatedly visited the national parks of western Lapland and the polypore flora of these areas is well known. KoskiKotiranta and Niemelä (1988) have mapped the distribution of some wood-inhabiting hydnaceous fungi in northwestern Europe.

Polypores are the best-known group of wood-inhabiting fungi in Finland. The polypore flora of Finland is generally well known and the polypore survey of Finland was undertaken (Niemelä 1982, Niemelä \& Kotiranta 1982, 1983, 1986) to summarize the present state of knowledge on the distribution of polypores. Restricted separate distributional and ecological studies of polypores have been made only in southern Finland (Laine 1967, Kotiranta \& Niemelä 1981, Erkkilä \& Niemelä 1986, Kotiranta \& Saarenoksa 1987).

Perhaps the very first contribution to the polypore flora of the North can be found in Linnaeus's (1737) Flora Lapponica, where the characters and traditional uses of Haploporus odorus (Somm.) Bond. \& Sing. were described. In the areas adjoining Finland, the most extensive studies of wood-inhabiting forest fungi have been made in Sweden. Romell (1911) was one of the first mycologists to publish taxonomical studies of the wood-inhabiting fungi of Lapland. Eriksson's (1958) extensive study of the taxonomy, ecology and pathogenicity of wood-inhabiting fungi in northern Sweden is one of the classical 
works on the mycoflora of Lapland. The polypore flora of Finnmark, northern Norway, has been studied by Ryvarden (1971), and an annotated floristic list of the higher fungi in the adjacent parts of the U.S.S.R. has been published by Shubin and Krutov (1979), but unfortunately the value of the latter otherwise important source of comparative observations is diminished by superficial and scanty documentation. Generally speaking, the North of the European U.S.S.R. is very poorly documented. Parmasto (1963) published a list from the Komi A.S.S.R., and a more thorough review of the Aphyllophorales flora of the Ural Mts. was made by Stepanova-Kartavenko (1967), Stepanova \& Demidova (1977) and Stepanova \& Mukhin (1979).

\section{The study area}

Finnish Eastern Lapland is a highland area with chains of mountains, known as fjelds. A major range, called Saariselkä, lies mostly in the fairly recently established Urho Kekkonen National Park. South of that range - in a wilderness area called Koilliskaira or Itäkaira - are numerous more separate peaks, some of them lying in the Värriö Strict Nature Reserve, our main study area. The gentle slopes of the fjelds and the barren, stony soil are evidence of repeated glaciations, the last of which ended in the area ca. 10000 years ago. The bedrock belongs to the granite-gneissic massive of northeastern Lapland (Perttunen 1984). The highest peaks within the study area and its immediate surroundings reach 615 metres, and the valleys in between have an altitude of $250-300 \mathrm{~m}$. In spite of their modest degree of elevation, all the major peaks reach well over the timberline, which lies at an approximate altitude of $400 \mathrm{~m}$. The explanation of the low elevation of the timberline is the northerly situation of the region, $130 \mathrm{~km}$ north of the Arctic Circle. The general landscape of the area is a complex of low, treeless fjeld tops, open timberline woodlands made up of the Mountain Birch (Betula pubescens subsp. czerepanovii) with scattered spruce, narrow strips of the Siberian Spruce (Picea abies subsp. obovata) in the valleys, and dry woodlands on sandy soils, in which the dominant tree is the Scots Pine (Pinus sylvestris).

The climate of the study area is continental and the mean annual temperature is -1 to $-2^{\circ} \mathrm{C}$. The annual precipitation varies between 450 and $500 \mathrm{~mm}$ (Anonymous 1987). The precipitation is high in comparison with the temperature (Kalliola 1973), and the growing season is therefore fairly humid.
The forests in and around the study area have recently attracted international attention because of the air pollution reaching Finland from the Soviet Union, especially from Nikel, Zapolyarnyy and Monchegorsk. The emissions originate from vast nickel, magnetite, copper and apatite mining and metallurgical centres, and have caused catastrophic environmental damage on the Kola Peninsula (cf. Yevseev et al. 1990). In addition to 250 million tons of solid wastes, the Kola industrial plants annually emit 800000 tons of toxic airborne pollutants (Kalabin 1990), including 500000 tons of sulphur dioxide (Parviainen 1990), and 10000 tons of heavy metals (Kalabin 1990). In the Kola area, a completely dead landscape is reported to cover 10000 hectares, but the area of heavily polluted land which may never recover is many times as great. The vegetation shows especially high concentrations of sulphur, nickel, cobalt and copper (Kalabin 1990). The forests in the adjacent areas of Norway and Finland have also suffered damage (Kauppi et al. 1990, Kubin 1990), but one recent exceptionally cold winter (1987-1988) has obscured the true scale of pollution-induced defects in the trees (Parviainen 1990). Extensive pine deaths have already been detected in some sites in northeastern Finland, in particular the parishes of Salla and Savukoski. Clearly damaged forest covers a few thousand hectares, but when only slight pollution-caused damage is included, the affected area is some tens of thousands of hectares (Anonymous 1990), perhaps 40000 . So far, however, our study area seems to lack tree deaths attributable to pollution. The predominantly northwesterly winds are favourable for the area and the exposure of the slopes reduces the amount of local dust deposition from the flue gas (cf. Yevseev et al. 1990). When the wind is blowing from the east or northeast, the atmospheric content of sulphur dioxide at the Värriö Research Station is ca. 50 micrograms per $\mathrm{m}^{3}$, but when the wind is southwesterly, the content is negligible (Anonymous 1990). Some recent severe forest epidemics (Jalkanen \& Laakso 1986, Parviainen 1990) in northeastern Finland have been attributed at least partly to stress caused by toxic flue gas.

Three separate forest areas were selected for the study (Figs. 1-2). We consider them to be particularly representative of the Northern Boreal virgin forests of eastern Lapland next to the timberline and as their forests also have very different histories, they allow a comprehensive view of the ecological processes in the area. Altogether, the study area covers about $125 \mathrm{~km}^{2}$. 

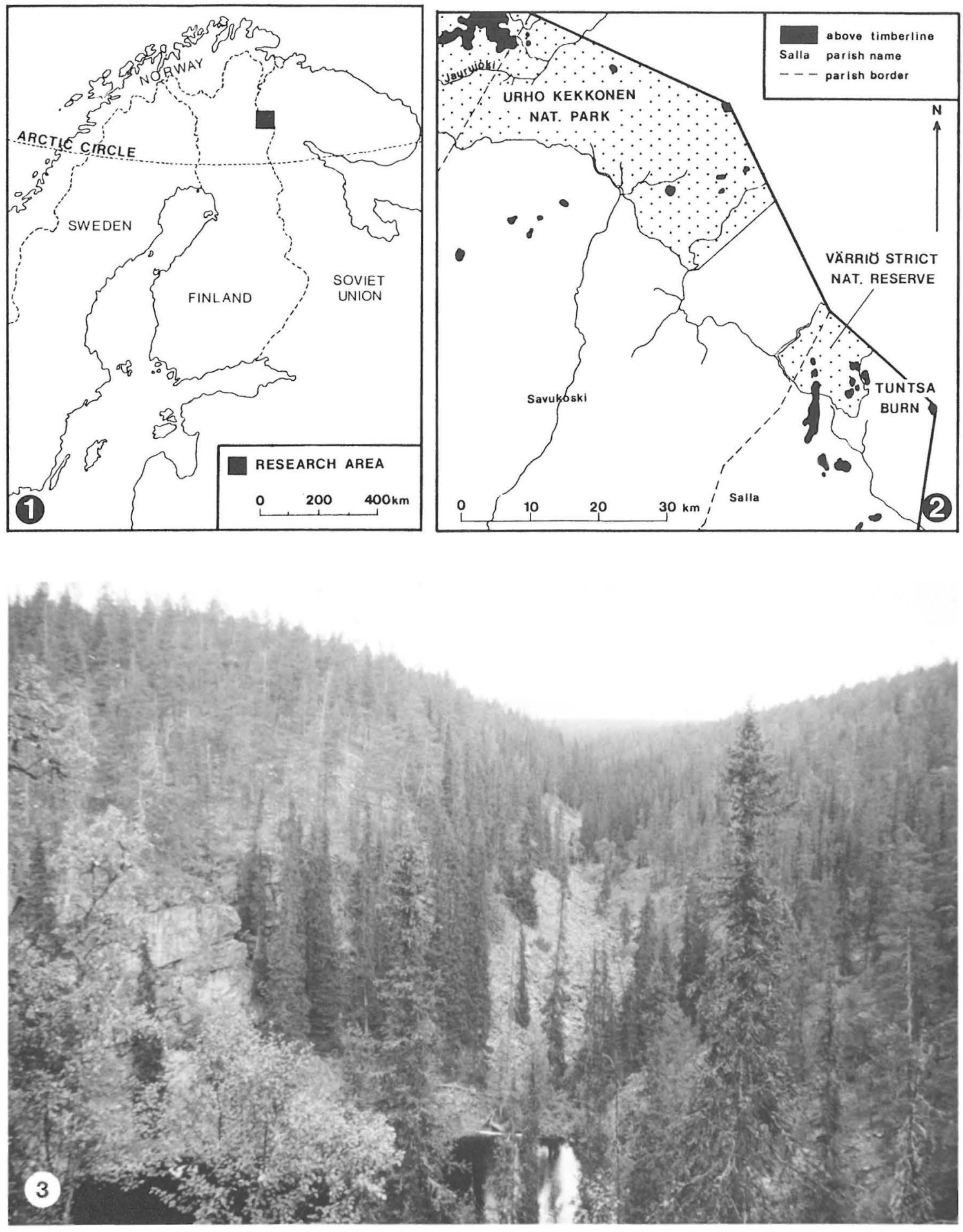

Figs. 1-3. The research area. - 1: The location of the area in northwestem Europe. - 2: A detailed map, showing nature reserves, parishes and some other names mentioned in the text. - 3: View over the Värriö Strict Nature Reserve, one of the last extensive virgin forests at the timberline in Finland. August 1989. 


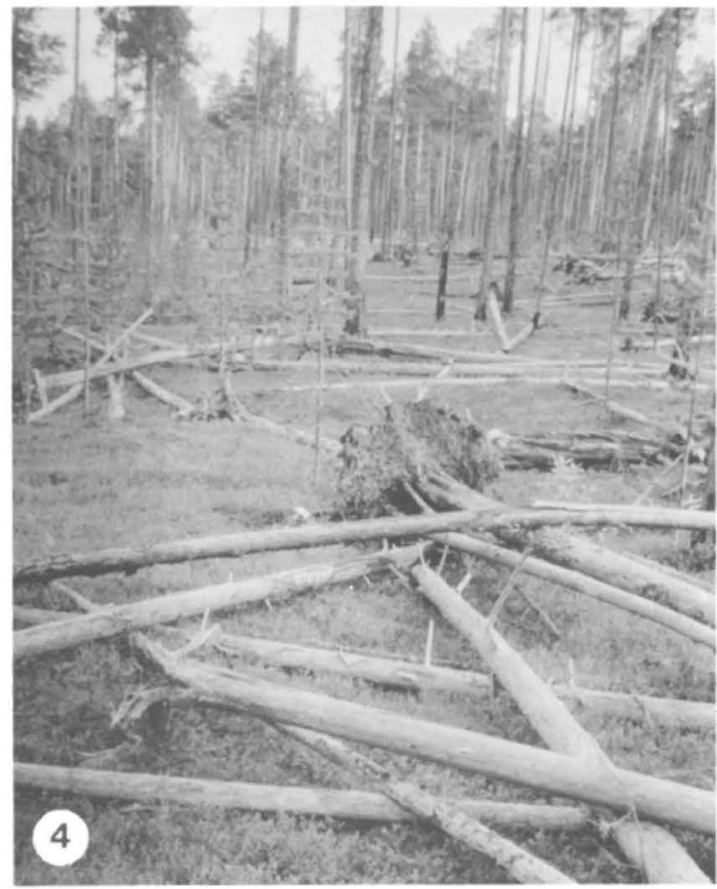

Figs. 4-5. Fallen trunks of the Scots Pine. - 4: Decorticated, mostly old windfalls in Värriob. August 1988. - 5: The area of the river Jaurujoki is characterized by extensive fresh windfalls of a storm in 1985. September 1988.

\section{The Värriö Strict Nature Reserve}

Most of the studies were made in the Värriö Strict Nature Reserve, which is situated in the parishes of Salla and Savukoski. It is delimited in the east by the boundary of the U.S.S.R. and covers an area of $110 \mathrm{~km}^{2}$. The reserve was selected for the study as representing undisturbed, peacefully developed forest in at least parts of which the dominant tree is spruce. It is one of the last extensive virgin regions at the timberline in Finland (Fig. 3). The forests have not been touched at all by forestry and are not divided by roads; even the Värriö Research Station in the reserve is not reached by a real road, but only by a track. A striking and characteristic feature is the great number of fallen and decaying trunks and natural stumps (Fig. 4). Human activities have been minimal and there is no permanent human population, though reindeer herding has been practised for at least two centuries. The Värriö Strict Nature Reserve was established in 1982. In the middle of the area lies the Värriö Research Station of the University of Helsin$\mathrm{ki}$, which includes a meteorological station.

The reserve contains some pools and many small rivers and brooks and is located on a watershed. There are rather few mires in the study area, in contrast to the general situation in northern Finland. These are predominantly small bogs, fens and swamps, usually bordering rivers and brooks. The

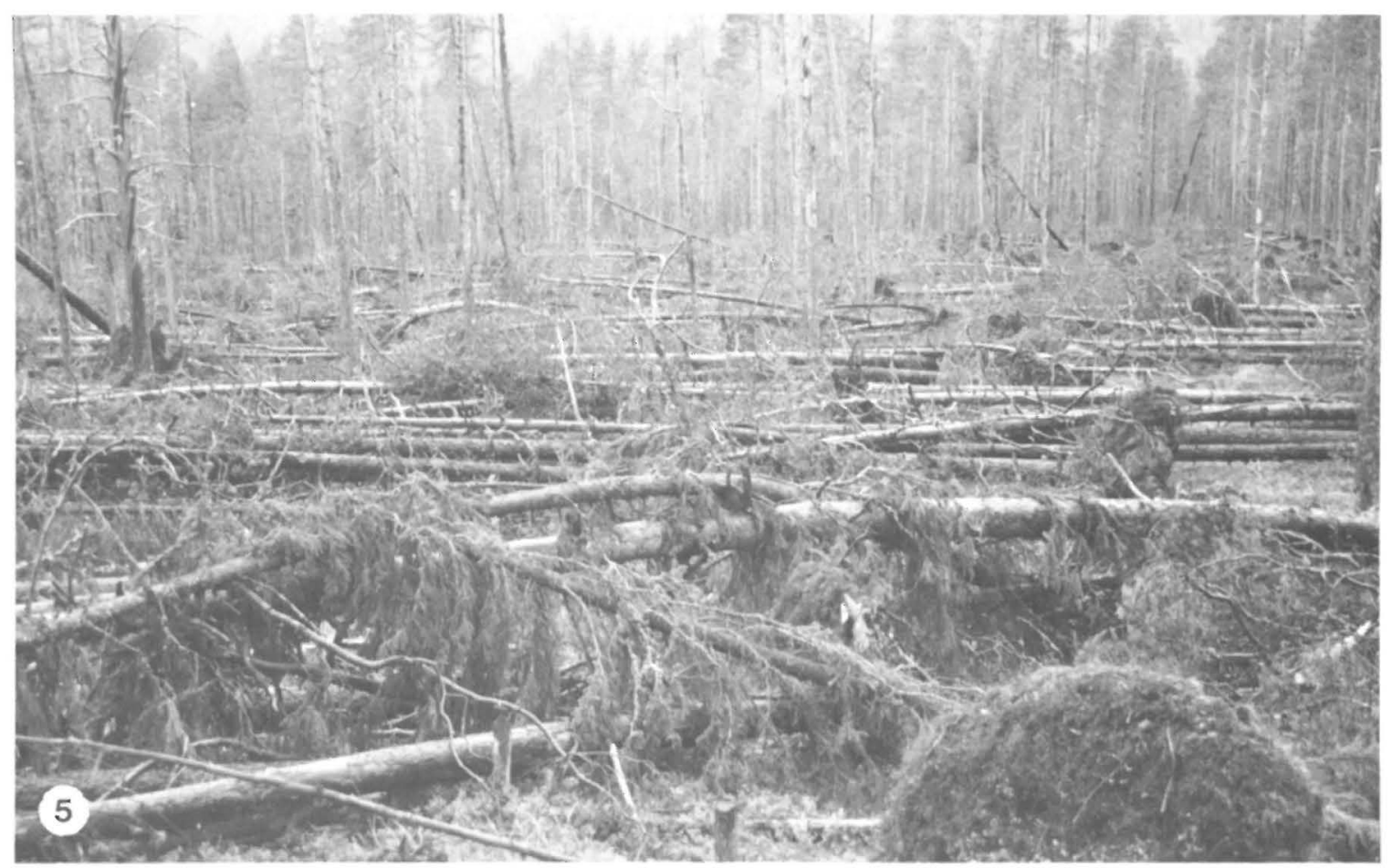




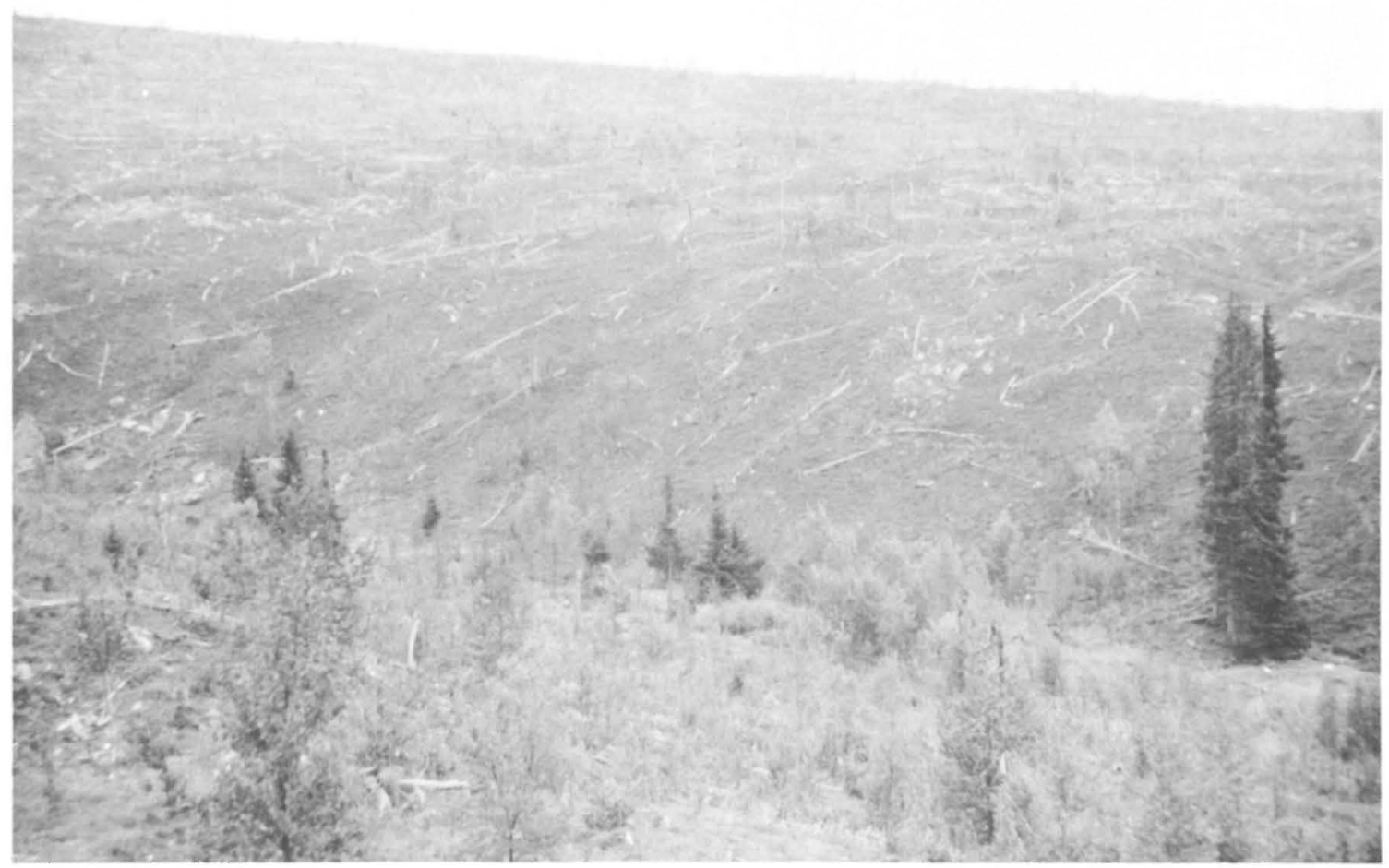

Fig. 6. The spruce forests of Tuntsa burned down in a natural fire in 1960. Thirty years after the fire, the landscape is still open and almost treeless. August 1988.

area is mostly situated over $300 \mathrm{~m}$ above sea level. Treeless heaths are common and fairly extensive on the fjeld tops.

The Värriö Reserve is surrounded by vast clearcut areas. In the adjacent Soviet Union, clear felling was carried out in 1960 after a large forest fire in the Tuntsa area. In these latitudes the regeneration of forests is uncertain and extremely slow, especially in areas which have been totally clear-cut.

\section{The area of the River Jaurujoki}

The Jaurujoki runs through the southeastern part of the Urho Kekkonen National Park, which is the largest $\left(2530 \mathrm{~km}^{2}\right)$ protected forest area in Finland.

We chose the valley of the Jaurujoki as our study area, because it offers extensive fresh windfalls in natural forests. Massive fallen tree trunks are rare in managed forests, and they have a special value for the survival of certain wood-inhabiting fungi. These windfalls are a striking element of the landscape (Fig. 5 ), and were mainly caused by a storm in 1985 .
Nationwide dispute arose after the storm about whether the tens of thousands of high-quality pine logs should be harvested from the Park or not, but finally they were left intact for reasons of nature conservation. Those recent windfalls gave us an opportunity to study the beginning of the natural succession of fungi on decaying trunks. The area of the Jaurujoki is characterised by dry and sparse pine (Pinus sylvestris) forests. Southwest of the river, extensive aapa mires predominate.

\section{The Tuntsa Burn}

Adjacent to the Värriö Strict Nature Reserve in the south is a large burnt area in the valley of the Tuntsa River. Natural, freely spreading forest fires almost never occur in northern Europe, due to the efficient fire control. However, fires have played a role in forest ecosystems in a natural state, and it is evident that many wood-rotting fungi have decreased - together with numerous insects and other animals, and plants - since the environment ceased to be drasti- 

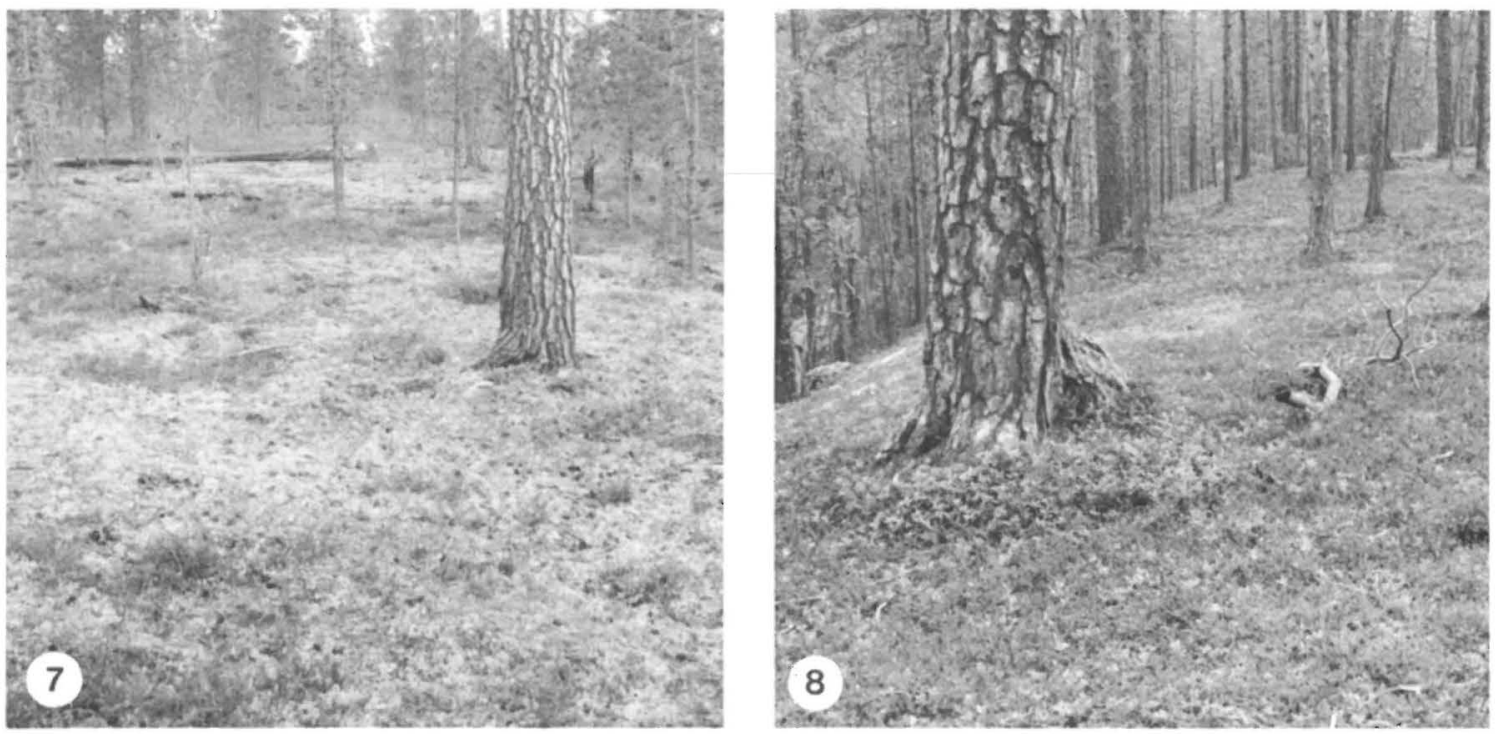

Fig. 7-8. Dry pine forests. - 7: The Uliginosum-Vaccinium-Empetrum type in Värriö. The field layer is low-growing and poor in species. August 1989. - 8: The Empetrum-Myrtillus type in Värriö. In the field layer Vaccinium myrtillus is fairly abundant. August 1989.

cally modified by the formerly frequent forest fires. In this respect biologists working in western Europe are unable to obtain information that is still available to their colleagues today in many sparsely inhabited areas of the Canadian North, Alaska and northern Asia, where forest fires are allowed to proceed freely, provided they do not threaten settlements or merchantable timber.

The Tuntsa Burn was caused by a natural forest fire in 1960. Trees left standing after the fire have mostly been cut down. Despite every effort to promote it, regeneration of the forest has largerly failed (Komulainen 1990). Thirty years after the fire, the landscape is still open, dry and almost treeless, resembling a vast clear-cut area or an open fjeld heath (Fig. 6). Along brooks are a few small tree stands, predominantly spruce, which escaped the fire, and were left uncut.

We chose this area because the groups of fallen, burnt and charred spruce trunks that occur in places present us with an opportunity to study fungi which grow on charred wood. The microclimate of the deforested slopes seems to be unfavourable to fungal growth in the same way as that of clear-cut areas. Hence, we could also obtain information on the effects of clear-cutting on the occurrence of wood-rotting fungi and the survival of fungal populations in these exposed habitats.

\section{The vegetation}

The study area lies in a slightly oceanic section of the Northern Boreal vegetation zone (Ahti et al. 1968). It is situated in a transitional area between the forest sections of Perä-Pohjola and Forest-Lapland. These sections have different forest site type systems, but in the study area the sites are often intermediate and cannot easily be allocated to the types proposed by Kalela (1961) and Kalliola (1973). Brief descriptions of the main forest types in the study area are given below.

\section{Dry pine forests}

There are two main types of dry Scots pine-dominated forest, which are both abundant all over the study area. The often rather sparse and uniform tree layer is composed almost exclusively of pine. The shrub layer is practically lacking and the herb and moss layers are poor in species, the former consisting mainly of a few dwarf shrubs, the latter of lichens and mosses.

The very dry pine woodlands growing chiefly on sandy soils belong to the Uliginosum-VacciniumEmpetrum type (UVET) distinguished by Kalela (1961) (Fig. 7). This type is a northern equivalent of the Calluna type (CT) in southern Finland (cf. Kallio- 


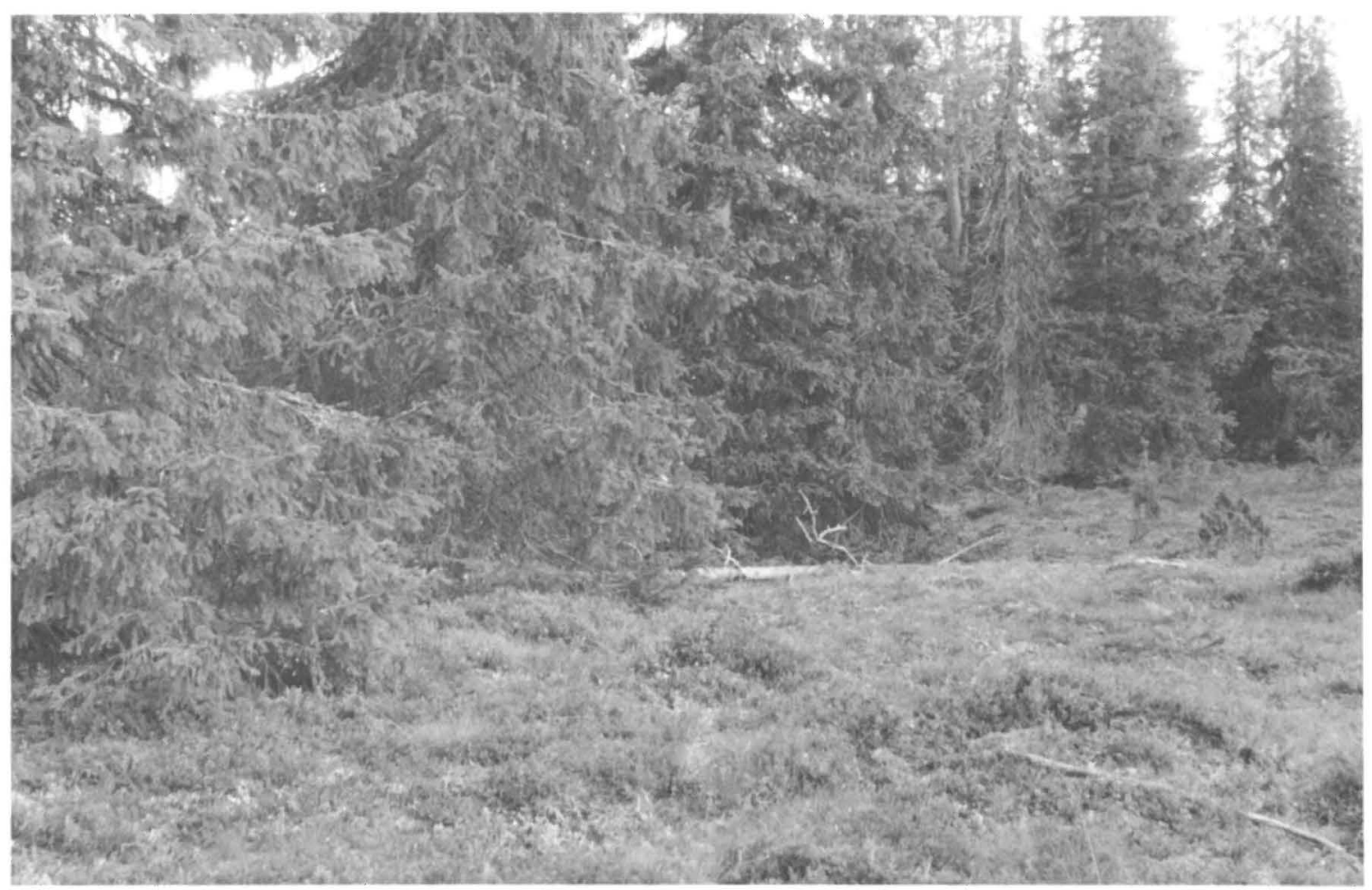

Fig. 9. Mesic spruce forest of the Hylocomium-Myrtillus type in the Värrio Strict Nature Reserve. August 1989.

la 1973). The field layer is very poor in species, lowgrowing and scanty, being formed by the dwarf shrubs Empetrum nigrum s. lat., Vaccinium vitisidaea, V. myrtillus, V. uliginosum and Calluna vulgaris. Lichens, especially Cladina mitis, C. arbuscula, C. rangiferina and $C$. stellaris, predominate in the ground layer, intermixed with the mosses Dicranum fuscescens, D. scoparium, Pleurozium schreberi and Polytrichum juniperinum.

Dry pine forests which are a little moister than the UVET and occur on sandy but mostly till soils, can be referred to the Empetrum-Myrtillus type (EMT; Kalela 1961) (Fig. 8). This is a northern equivalent of the Vaccinium type (VT) in southern Finland (cf. Kalliola 1973) and differs from the UMET in the following characters: in the tree layer spruce is sometimes intermixed with pine, but the latter is strongly predominant. In the field layer Vaccinium myrtillus is particularly abundant. The ground layer is formed by Pleurozium schreberi, Cladina rangiferina and $C$. arbuscula, often together with Dicranum fuscescens, D. scoparium and Nephroma arcticum.

\section{Mesic spruce forests}

The spruce predominates on moister till soils, forming open and well-illuminated rather than dense stands. These spruce forests usually occur on ridges or slopes of the fjelds, denser and richer forests being found in the valleys of small rivers, and brook ravines on soils affected by spring flooding. Mesic spruce forests are especially abundant in the Värriö area.

The open and sparse spruce forests on the ridges of fjelds can be referred to the Hylocomium-Myrtillus type (HMT; Kalela 1961). This is a northern equivalent of the Myrtillus type (MT) in southern Finland. The tree layer is composed mainly of spruce, but birches often grow among the spruce, especially in the post-fire forest succession.

The field layer is dense compared with that in pine woodlands (Fig. 9). It is formed by dwarf shrubs together with grasses and other herbaceous plants. The most abundant species is Vaccinium myrtillus but a considerable part of the biomass is contributed by other dwarf shrubs, e.g. Linnaea borealis, 


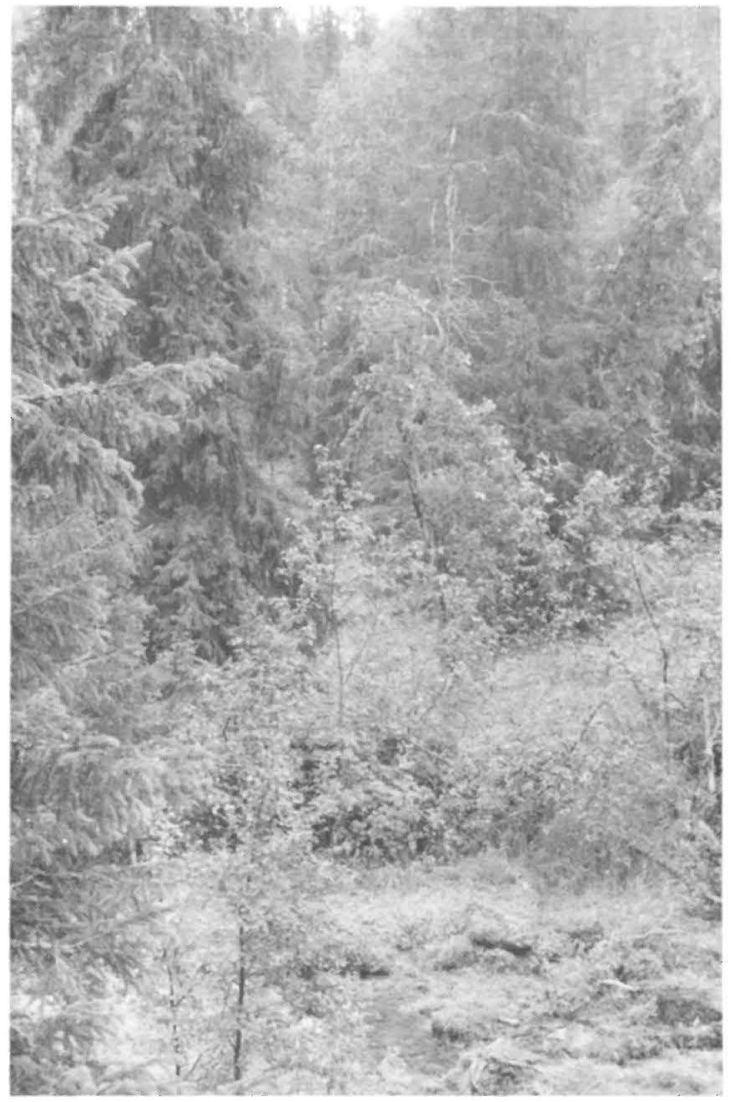

Fig. 10. Brookside forest in the Värriö Strict Nature Reserve. Betula pubescens, Sorbus aucuparia, Ribes spicatum, Salix species and Picea abies ssp. obovata. August 1989.

Empetrum nigrum, Ledum palustre (Rhododendron tomentosum (Stokes) Harmaja, Harmaja 1990) and Vaccinium uliginosum. The herbs Deschampsia flexuosa, Luzula pilosa, Melampyrum pratense, Solidago virgaurea and Trientalis europaea are also very abundant.

The moss layer is usually thick, very soft and dense, being formed mainly by Hylocomium splendens and Pleurozium schreberi. Other abundant species are Dicranum majus, Polytrichum commune and Barbilophozia lycopodioides. The commonest lichens are Nephroma arcticum and Peltigera aphtosa.

\section{Brookside forests}

In brook ravines, and the valleys of small rivers, especially on soils affected by spring flooding, the spruce forests are denser and richer than those de- scribed above. Tree growth is better, and the trees are taller and usually much thicker than in pure forests of the HMT. Although usually forming only a narrow belt of 5 to $30 \mathrm{~m}$ by the brooks, most of these gallery forests have lush grass-herb vegetation. Shrubs and exacting forbs are especially well represented, compared with their occurrence in the other vegetation types of the study area (Fig. 10).

In the tree layer spruce is abundantly intermixed with Salix caprea, Sorbus aucuparia and Betula pubescens. Populus tremula grows almost exclusively on warm dry south-facing slopes. Alnus incana subsp. kolaënsis is restricted to a few wet swampy sites along some brooks. Prunus padus subsp. borealis and Ribes spicatum form the shrub layer on the most luxuriant sites. In the field layer the most abundant species are Cornus suecica, Deschampsia flexuosa, Geranium sylvaticum, Gymnocarpium dryopteris, Vaccinium myrtillus and V. vitis-idaea. Other significant species are Luzula pilosa, Maianthemum bifolium, Melampyrum pratense, Melica nutans and Rubus saxatilis.

Some features of vascular plant flora in the study area

Chiefly because of the washed-out soils and acidic nutrient-poor bedrock, the vascular plant flora is relatively poor in species. Floristically, the study area is situated in a transitional belt between the southern and northern elements, perhaps also between the continental and oceanic elements (cf. Rintanen 1970b, Airola \& Pulliainen 1975).

The vascular plant flora is richest in deep valleys and in meadows along brooks and rivers inundated by the spring floods. The most outstanding of such meadows are composed of Calamagrostis purpurea, C. stricta, Elymus caninus, Lactuca sibirica, Phalaris arundinacea and Veronica longifolia. Characteristic species of grass-herb forests bordering brooks are Angelica archangelica, Carex brunnescens var. laetior, C. loliacea, Luzula parviflora and Vahlodea atropurpurea.

Springs affect the vegetation in their surroundings and the flora of these permanently wet sites has its own features. The chief species favouring these sites are Alchemilla glomerulans, Epilobium hornemannii and Stellaria calycantha, and the mosses Philonotis fontana, Pohlia wahlenbergii, Rhizomnium magnifolium and Warnstorfia exannulata. Along the brooks are wet, swampy thickets formed by willows. Salix glauca and S. lapponum are especially abundant, and sometimes form extensive, almost impenetrable stands. 
The following list contains the woody plants which can serve as hosts for decay fungi in our study area:

\section{Juniperus communis}

Picea abies subsp. obovata (Siberian Spruce)

Pinus sylvestris

Alnus incana subsp. kolaënsis
Betula nana
B. pendula
B. pubescens subsp. czerepanovii (subsp. tortuosa s.
$\quad$ auct., Mountain Birch)
B. pubescens subsp. pubescens
Populus tremula
Prunus padus subsp. borealis
Ribes spicatum
Salix borealis
S. caprea
S. glauca
S. hastata
S. lanata
S. lapponum
S. myrsinifolia
S. phylicifolia
S. starkeana
Sorbus aucuparia

Acknowledgements. We are indebted to the Academy of Finland for financing our studies. The field work in 1987 was supported by the Finnish Council for Forest Reserves. Prof. Teuvo Ahti (Helsinki) kindly revised the entire paper, improving especially the phytogeographic and floristic sections. Dr. Seppo Huhtinen (Turku) helped us to avoid some botanical potholes in the path of manuscript preparation. We are grateful to the personnel of the Värriö Research Station, particularly the cook, for help and encouragement during our field study. Ms. Sanna Laaka, M. Sc., (Helsinki) assisted us in identifying some bryophytes and Ms. Anna A. Damström, M.A., revised the English of this paper.

\section{References}

Ahti, T. 1989: Jäkälien määritysopas. - Helsingin yliop. kasvit. lait. monist. 118:1-77.

Ahti, T., Hämet-Ahti, L. \& Jalas, J. 1968: Vegetation zones and their sections in northwestern Europe. - Ann. Bot. Fennici 5:169-211.

Airola, H. \& Pulliainen, E. 1975: Itäkaira-Koilliskairan kansallispuistosuunnitelman osa. - Suomen Luonto 3: 157-162.

Anonymous 1987: Vihko 131. Ilmasto. - 32 pp. Maanmittaushallitus \& Suomen maantieteellinen seura, Helsinki.

Anonymous 1990: Tuhansia hehtaareja metsää vaurioitunut Koillis-Lapissa. - Helsingin Sanomat 28.III.1990: A6.

Eriksson, J. 1958: Studies in the Heterobasidiomycetes and Homobasidiomycetes - Aphyllophorales of Muddus Na- tional Park in North Sweden. - Symb. Bot. Upsalienses 16:1-172.

Eriksson, J. \& Ryvarden, L. 1973: The Corticiaceae of North Europe 2. Aleurodiscus-Confertobasidium. - Pp. 55-261. Fungiflora, Oslo.

Eriksson, J. \& Strid, A. 1969: Studies in the Aphyllophorales (Basidiomycetes) of northern Finland. - Rep. Kevo Subarctic Res. Sta. 4:112-158.

Erkkilä, R. \& Niemelä, T. 1986: Polypores in the parks and forests of the City of Helsinki. - Karstenia 26:1-40.

Gilbertson, R.L. \& Ryvarden, L. 1986: North American polypores 1. Abortiporus-Lindtneria. - Pp. 1-433. Fungiflora, Oslo.

Gilbertson, R.L. \& Ryvarden, L. 1987: North American polypores 2. Megasporoporia-Wrightoporia. - Pp. 434 885. Fungiflora, Oslo.

Greuter, W., Burdet, H.M., Chaloner, W.G., Demoulin, V., Grolle, R., Hawskworth, D.L., Nicolson, D.H., Silva, P.C., Stafleu, F.A., Voss, E.G. \& McNeill, J. 1988: International Code of Botanical Nomenclature. - Regnum Vegetabile 118:1-328.

Haapasaari, M. 1988: The oligotrophic heath vegetation of northern Fennoscandia and its zonation. - Acta Bot. Fennica 135:1-219 + App.: Tables 1-23.

Harmaja, H, 1990: New names and nomenclatural combinations in Rhododendron (Ericaceae). - Ann. Bot. Fennici 27:203-204.

Hämet-Ahti, L., Palmén, A., Alanko, P. \& Tigerstedt, P.M.A. 1989: Suomen puu- ja pensaskasvio. - 290 pp. Dendrologian seura, Helsinki.

Hämet-Ahti, L., Suominen, J., Ulvinen, T., Uotila, P. \& Vuokko, S. (eds.) 1986: Retkeilykasvio. — 598 pp. Suomen Luonnonsuojelun Tuki Oy, Helsinki.

Jalkanen, R. \& Laakso, R. 1986: Hendersonia acicola in an epidemic caused by Lophodermella sulcigena with special reference to biological control. - Karstenia 26:49-56.

Jülich, W. 1984: Die Nichtblätterpilze, Gallertpilze und Bauhpilze (Aphyllophorales, Heterobasidiomycetes, Gastromycetes). In: Gams, H. (ed.), Kleine Kryptogamenflora $2 \mathrm{~b}(1)$, Basidiomyceten 1. - 626 pp. Springer Verlag, Stuttgart \& New York.

Kalabin, G. 1990: Untitled statistical information. In: Anonymous (ed.), Suomalaiset vaativat Kuolan päästöjen ripeää supistamista. - Helsingin Sanomat 3.IV.1990: A5.

Kalela, A. 1961: Waldvegetationszonen Finnlands und ihre klimatischen Paralleltypen. - Arch. Soc. Vanamo 16 (suppl.): 65-83.

Kallio, P. \& Kankainen, E. 1964: Notes on the macromycetes of Finnish Lapland and adjacent Finnmark. - Rep. Kevo Subarctic Res. Sta. 1:178-235.

Kallio, P. \& Kankainen, E. 1966: Additions to the mycoflora of northernmost Finnish Lapland. - Rep. Kevo Subarctic Sta. 3:177-210.

Kalliola, R. 1973: Suomen kasvimaantiede. -308 pp. WSOY, Porvoo.

Karsten, P. 1866: Enumeratio fungorum et myxomycetum in Lapponia orientali aestate 1861 lectorum. - Not. Sällsk. Fauna Flora Fennica Förh. 8 (N.S. 5): 193-224.

Kauppi, P., Anttila, P. \& Kenttämies, K. (eds.) 1990: Acidification in Finland. - 1237 pp. Springer Verlag, Berlin \& Heidelberg.

Komulainen, A. 1990: Tuhojen Tuntsa. - Suomen Luonto 49:18-19. 
Koponen, T., Isoviita, P. \& Lammes, T. 1977: The bryophytes of Finland. An annotated checklist. - Flora Fennica 6:1-77.

Koski-Kotiranta, S. \& Niemelä, T. 1988: Hydnaceous fungi of the Hericiaceae, Auriscalpiaceae and Climacodontaceae in northwestern Europe. - Karstenia 27:43-70.

Kotiranta, H. \& Larsson, K.-H. 1989: New or little collected corticolous fungi from Finland (Aphyllophorales, Basidiomycetes). - Windahlia 18:1-14.

Kotiranta, H. \& Niemelä, T. 1981: Composition of the polypore communities of four forest areas in southern central Finland. - Karstenia 21:31-48.

Kotiranta, H. \& Saarenoksa, R. 1987: Kumpulan laakson sienilajistosta 1. Kääväkkäät. — Sienilehti 39:5-11.

Kotiranta, H. \& Saarenoksa, R. 1990: Reports of Finnish corticolous Aphyllophorales (Basidiomycetes). — Karstenia 30:43-69.

Kubin, E. 1990: A survey of element concentrations in the epiphytic lichen Hypogymnia physodes in Finland in 19851986. In: Kauppi, P., Anttila, P. \& Kenttämies, K. (eds.), Acidification in Finland, pp. 421-446. - Springer Verlag, Berlin \& Heidelberg.

Kytövuori, I. 1989a: The Tricholoma caligatum group in Europe and North Africa. - Karstenia 28:65-77.

Kytövuori, I. 1989b: Tuoksuvalmuskat (Tricholoma caligatum-ryhmä) pohjoismaissa. - Sienilehti 41:5-9.

Kytövuori, I. 1989c: Kermavalmuska (Tricholoma roseoacerbum) ja jättivalmuska (Megatricholoma colossus), kaksi harvinaista valmuskaa. - Sienilehti 41:77-81.

Laine, L. 1967: Notes of the polypores (Polyporaceae) of Ahvenanmaa. - Karstenia 8:14-20.

Laurila, M. 1939: Basidiomycetes novi rarioresque in Fennia collecti. - Ann. Bot. Soc. Vanamo 10(4): 1-25.

Linnaeus, C. 1737: Flora Lapponica. - 372 pp. Schouten, Amstelaedami.

Niemelä, T. 1985a: On Fennoscandian polypores 9. Gelatoporia n. gen. and Tyromyces canadensis, plus notes on Skeletocutis and Antrodia. - Karstenia 25:21-40.

Niemelä, T. 1985b: Mycoflora of Poste-de-la-Baleine, northem Quebec. Polypores and the Hymenochaetales. - Naturaliste Canadien 112:445-472:

Niemelä, T. 1988: Suomen kääpien määritysopas. - Helsingin yliop. kasvit. lait. monist. 110:1-96.

Niemelä, T. \& Kotiranta, H. 1982: Polypore survey of Finland 2. The genus Phellinus. - Karstenia 22:27-42.

Niemelä, T. \& Kotiranta, H. 1983: Polypore survey of Finland 3. The genera Coltricia, Inonotopsis, Inonotus and Onnia. - Karstenia 23:15-25.

Niemelä, T. \& Kotiranta, H. 1986: Polypore survey of Finland 4. Phaeolus, Fistulina, Ganoderma and Ischnoderma. - Karstenia 26:57-64.

Norokorpi, Y. 1979: Old Norway spruce stands, amount of decay and decay-causing microbes in northern Finland. Commun. Inst. For. Fenniae 97(6): 1-77.

Parmasto, E. 1963: K mikologicheskoy flore Komi ASSR. Tartu Riikliku Ülikooli Toim., Botaanika-alased Tő̈d 6:103-130.

Parviainen, J. 1990: Vain pikaiset rajoitukset pelastavat itärajan metsăt. — Helsingin Sanomat 7.VIII.1990: A2.

Perttunen, V. 1984: Pohjois-Suomen kallioperä. - Acta Lapponica Fenniae 12:8-26.

Rassi, P., Alanen, A., Kemppainen, E., Vickholm, M. \& Väisänen, R. (eds.) 1986: Uhanalaisten eläinten ja kasvien suojelutoimikunnan mietintö 3 . Suomen uhanalaiset kas- vit. Komiteanmietintö 1985(43). — 431 pp. Ympäristöministeriö, Helsinki.

Rassi, P. \& Väisänen, R. 1987: Threatened animals and plants in Finland. English summary of the report of the Committee for the Conservation of Threatened Animals and Plants in Finland. - 82 pp. Ympäristöministeriö, Helsinki.

Renvall, P. 1989: Kaatuneiden kuusien (Picea abies) ja mäntyjen (Pinus sylvestris) kääväkäslajisto luonnontilaisessa pohjoisboreaalisessa metsässä Itä-Lapissa. - $70 \mathrm{pp}$. Unpubl. M.Sc. thesis, Dept. Bot., Univ. Helsinki.

Renvall, P. \& Niemelä, T. 1990: The succession of woodrotting fungi on conifers in a Northern Boreal ecosystem. In: Reisinger, A. \& Bresinsky, A. (eds.), Fourth International Mycological Congress. Abstracts, p. 150. - Univ. Regensburg, Regensburg.

Renvall, P., Renvall, T. \& Niemelä, T. 1991: Basidiomycetes at the timberline in Lapland 2. An annotated check-list of the polypores of northeastern Finland. - Karstenia $31: 13-28$.

Renvall, T. 1989: Värriön luonnonpuiston kääpälajisto. - 57 pp. Unpubl. M.Sc. thesis, Dept. Bot., Univ. Helsinki.

Rintanen, T. 1968: The distribution of fjeld plants in eastern Lapland. - Ann. Bot. Fennici 5:225-305.

Rintanen, T. 1970a: On the vegetation and ecology of frost ground sites in eastern Finnish Lapland. - Ann. Bot. Fennici 7:1-24.

Rintanen, T. 1970b: Floristic areas distinguished in eastern Finnish Lapland on the basis of fjeld plant distribution. Ann. Bot. Fennici 7:353-374.

Rintanen, T. 1978: Itä-Lapin tunturikasvit. - Acta Lapponica Fenniae 10:52-55.

Romell, L. 1911: Hymenomycetes of Lappland. - Arkiv Bot. 11(3): 1-35.

Ryvarden, L. 1971: Studies in the Aphyllophorales of Finnmark, northern Norway. - Rep. Kevo Subarctic Res. Sta. 8:148-154

Ryvarden, L. 1976: The Polyporaceae of North Europe 1. Albatrellus-Incrustoporia. - Pp. 1-214. Fungiflora, Oslo.

Ryvarden, L. 1978: The Polyporaceae of North Europe 2. Inonotus-Tyromyces. - Pp. 215-507. Fungiflora, Oslo.

Shubin, V.I. \& Krutov, V.I. 1979: Griby Karelii i Murmanskoy oblasti. - 104 pp. Nauka, Leningrad.

Stepanova-Kartavenko, N. 1967: Afilloforovye griby Urala. - 295 pp. Akademiya Nauk SSSR, Sverdlovsk.

Stepanova, N.T. \& Demidova, Z.A. (eds.) 1977: Mikologicheskie issledovaniya na Urale. - 112 pp. Akademiya Nauk SSSR, Sverdlovsk.

Stepanova, N.T. \& Mukhin, B.A. 1979: Osnovy ekologii derevorazrushayushchikh gribov. -100 pp. Nauka, Moskva.

Ulvinen, T. 1963: Beobachtungen über die Pilze von Savukoski, Nordfinnland. - Aquilo, Ser. Bot. 1:53-58.

Ulvinen, T., Ohenoja, E., Ahti, T. \& Alanko, P. 1989: A check-list of the fungi (incl. lichens) of the Koillismaa (Kuusamo) biological province, NE Finland. - Oulanka Reports 2:1-64.

Yevseev, A.V., Krasovskaya, T.M. \& Petrukhin, V.A. 1990: Ecologic-geographic fundamentals of the background monitoring in the Soviet trans-polar regions. In: Proc. Conf. Arctic and Nordic Countries Coord. Res. in the Arctic (Leningrad, December 1988) 1, pp. 255-262. - Nauka, Moskva.

Received on 20 August 1990 